\title{
Yield Gap Analysis through Front Line Demonstration in Castor
}

\author{
P.J. Prajapati ${ }^{*}$, N.S. Joshi, M.L. Patel and V.S. Parmar \\ Krishi Vigyan Kendra, JAU, Amreli, Gujarat, India \\ *Corresponding author
}

\section{A B S T R A C T}

\section{Keywords}

Frontline demonstration technology, Castor, Yield gap, Technology index, Economics

Article Info

Accepted:

12 October 2018

Available Online:

10 November 2018
Front line demonstration is an effective and appropriate tool to demonstrate recommended technologies among the farmers. Krishi Vigyan Kendra, JAU, Amreli conducted 30 demonstrations on castor during 2015-16 to 2017-18 in the villages of Amreli district. The study found, the yield of castor in IT under irrigated conditions ranges from 25.70 to 27.85 $\mathrm{q} /$ ha whereas in FP it ranges between 19.45 to $22.31 \mathrm{q} / \mathrm{ha}$. The per cent increase in yield with IP over FP was recorded in the range of 18.5 to $32.1 \%$. The extension gap and technological index were ranging from 4.1 to $6.3 \mathrm{q} /$ ha and 2.2 to 4.3 per cent, respectively. The trend of technology gap reflected the farmer's cooperation in carrying out demonstrations with encouraging results in subsequent years. The cost benefit ratio was 2.72 to 4.01 under demonstration, while it was 1.67 to 3.14 under control plots. By conducting front line demonstration of proven technologies, yield potential of castor crop could be enhanced to a great extent with increase in the income level of the farming community.

\section{Introduction}

Castor (Ricinus communis L.) is an important non-edible oilseed crop of the arid and semiarid regions of the world, where in India has the maximum area and production under this crop. Other important castor producing countries are China, Brazil, Russia and Thailand.

In Gujarat, the crop is grown in an area of 7.5 lakh hectares with a total production of 14.9 lakh tones and productivity $19.99 \mathrm{~kg} / \mathrm{ha}$ in the year 2012-13 (Anonymous, 2013). Gujarat, Andhra Pradesh, Rajasthan, Orissa and Karnataka are major castor producing states in India.
Front Line Demonstration (FLD) was started in castor to generate production data and feedback information to various development agencies, which are engaged in dissemination of technological advances through researchers to the farmer's fields. Increasing the productivity and improving the economic condition of the farmers, depends on the level of knowledge and skills of the farmers.

Front Line Demonstration (FLD) was started in castor to generate production data and feedback information to various development agencies, which are engaged in dissemination of technological advances through researchers to the farmer's fields. Thirty FLDs were conducted from 2015-16 to 2017-18 in Amreli 
district of Gujarat to demonstrate the improved castor production technologies that are suitable for that particular eco-system. The concurrent impact of such demonstrations is given in (Table 1). An attempt was made to analyze the impact of the demonstrations in vertical and lateral spread of the technologies and the resultant improvement in yield and income of the castor growers, with the following objectives: (a) to document the profile characteristics of castor growers; (b) to assess the knowledge and adoption level of castor growers in Amreli district of Gujarat as an impact of FLDs; (c) to assess the impact of frontline demonstrations on yield and income obtained by the oilseed growers; (d) to delineate the constraints encountered by the castor growers in Amreli district of Gujarat and (e) to suggest strategies to improve the castor cultivation scenario in Gujarat.

It was found that farmers were using traditional old varieties of castor crop without proper use of recommended scientific package of practices.

Keeping in view the constraints, KVK, Amreli conducted front line demonstrations on major castor crop which would ensure livelihood and economic empowerment of tribal households at faster pace.

\section{Materials and Methods}

The present study was carried out during the year 2015-16 to 2017-18 in the (Amreli, Vankiya, Tarvda, Gopalgram, Randhiya, Boradi, Babapur, Champathal, Manchiyala Mota and Devaliya Mota) villages of Amreli district of Gujarat. Thirty numbers of demonstrations was conducted in different villages with an objective to identify the yield gaps as well as to work out the difference in input cost and monetary returns under front line demonstrations and farmers' practices (local checks) of castor crop.
The critical inputs were applied as per the scientific package of practices recommended by the Main Oilseeds Research Station, JAU, Junagadh (Gujarat) and Castor and Mustard Research Station, SDAU, Dantiwada (Gujarat) (Table 1). The component demonstration of front line technology in castor was comprised of improved hybrids GCH-7, proper tillage, proper seed rate and sowing method, balance dose of fertilizer, seed treatment, proper irrigation, weed management and protection measure (Table 1). The data on production cost and monetary returns were collected for three years (2015-16 to 2017-18) from front line demonstration plots to work out the economic feasibility of improved and scientific cultivation of castor. Besides, the data from local checks, data were also collected where farmers were using their own practices for cultivation of castor crops. The technology gaps, extension gaps and technology index were calculated as given by (Samui et al., 2000) as:

Demonstration yield farmers yield Percent increase yield = ----------------- X 100 Farmers yield

Technology gap $=$ Potential yield Demonstration yield

Extension gap $=$ Demonstration yield - Yield from farmers practice (Local check)

Potential yield Demonstration yield Technology index = ------------------ X 100 Potential yield

\section{Results and Discussion}

\section{Description of front line demonstrations}

Results of 30 numbers of front line demonstrations conducted during 2015-16 to 2017-18 in 12 ha area on farmer's field on different villages of Amreli district indicated 
that the cultivation practices of improved variety recommended under irrigated conditions i.e. GCH-7, line sowing, with balanced application of fertilizers (75:50:0 kg NPK/ha).

\section{Technology intervention and farmers practice under FLD on castor}

The gap between the existing and recommended technologies of castor in district Amreli presented in (Table 1). Full gap was observed in case of use of high yielding hybrids and seed treatment and in case sowing method and weed management observed partial gap which definitely was the reason of not achieving potential yield. Farmers were not aware about recommended technologies. Farmers in general used local or old-age varieties instead of the high yielding resistant varieties.

Unavailability of seed in time and lack of awareness were the main reasons. In plant protection measures farmers used uneven pesticide and high dose of pesticides so their cost increases.

Economic impact of front line demonstrations

During the period of study, the inputs and outputs prices of commodities prevailed during each year of demonstrations were taken for calculating cost of cultivation, net return and benefit cost ratio (Table 2).

The economic analysis under front line demonstrations in improved technologies (IT) recorded higher productivity of seed yield (27.85 q/ha) in the year 2016-17. Percentage increase $(32.13 \%)$ over local check was higher in the year 2015-16 and in case of gross returns (Rs. $115915 \mathrm{ha}^{-1}$ ) and B: C ratio (4.01) higher as compared to the local checks in the year 2016-17 but additional net returns (Rs. 28090/ha) was higher in the year 2015-16. This results clearly indicated higher productivity of castor under improved technologies plots over the years compare to local check due to knowledge and adoption of full package of practices i.e. sowing of latest high yielding hybrids, adoption of improved nutrient, moderate disease resistant hybrid, adoption of improved weed and pest management techniques. Similar results have been reported earlier by Padmaiah et al., (2012) and Kumar et al., (2015).

The year wise fluctuation in yields was observed mainly on the account of variations in soil fertility status, climate and moisture availability.

\section{Technology gap}

The technology gap shows the gap in the demonstration yield over potential yield and it was highest $(4.3 \mathrm{q} / \mathrm{ha})$ in the year 2015-16 in comparison to year 2017-18 (3.6 q/ha) and year 2016-17 (2.0 q/ha). On an average technology gap under three year FLD programme was $3.6 \mathrm{q} / \mathrm{ha}$.

The observed technology gap was mainly attributed to poor irrigation water in the district. The other reasons include dissimilarity in soil fertility status, agricultural practices and local climatic situation. This finding is supported by Romade et al., (2018).

\section{Extension gap}

Further the higher extension gap of $6.3 \mathrm{q} / \mathrm{ha}$ and $4.1 \mathrm{q} / \mathrm{ha}$ was recorded in the year 2015-16 and 2017-18 respectively as compare to the year 2016-17 (3.7 q/ha). This emphasized the need to educate the farmers through various extension means i.e. front line demonstration for adoption of improved production and protection technologies, to revert the trend of wide extension gap. 
Table.1 Difference between technology intervention and farmers practice under FLD on castor

\begin{tabular}{|c|c|c|c|}
\hline Particulars & Technology intervention & Existing practice & Gap \\
\hline Hybrid & GCH-7 & Old\& degenerated & Full gap \\
\hline $\begin{array}{l}\text { Land } \\
\text { preparation }\end{array}$ & Three ploughing & Three ploughing & Nil \\
\hline Seed rate & $8-10 \mathrm{~kg} / \mathrm{ha}$ & $15-20 \mathrm{~kg} / \mathrm{ha}$ & Higher seed rate \\
\hline Sowing method & $\begin{array}{l}\text { Line sowing } \\
(120 X 90 \mathrm{~cm})\end{array}$ & $\begin{array}{l}\text { Line sowing } \\
(120-150 \text { X } 90-120 \\
\mathrm{cm})\end{array}$ & Partial gap \\
\hline Seed treatment & $\begin{array}{l}\text { Trichoderma powder @ 5-10 } \\
\text { g/kg of seeds and } \\
\text { Azospirillum or Phosphorus } \\
\text { Solublizing bacteria@ } 50 \text { gm } \\
\text { /kg }\end{array}$ & No seed treatment & Full gap \\
\hline Fertilizer dose & (75:50:0 kg NPK/ha) & $\begin{array}{l}\text { 75-100:50-70:00 } \\
\text { NPK/ha }\end{array}$ & Apply high fertilizer \\
\hline $\begin{array}{l}\text { Weed } \\
\text { management }\end{array}$ & $\begin{array}{l}\text { Pre-emergence application of } \\
\text { Pendimethalin @ } 0.9 \mathrm{~kg} \text { a.i./ha } \\
\text { along with two inter-culturing } \\
\text { and two hand weeding } \\
\text { operations at } 30 \text { and } 60 \text { DAS }\end{array}$ & $\begin{array}{l}\text { One or two hand } \\
\text { weeding }\end{array}$ & Partial gap \\
\hline $\begin{array}{l}\text { Plant } \\
\text { protection }\end{array}$ & $\begin{array}{l}\text { Need based plant protection } \\
\text { measure }\end{array}$ & $\begin{array}{l}\text { Used different } \\
\text { pesticides }\end{array}$ & $\begin{array}{l}\text { Uneven use of } \\
\text { pesticide }\end{array}$ \\
\hline
\end{tabular}

Table.2 Economics of castor production under frontline demonstrations and farmers practice in Amreli district

\begin{tabular}{|c|c|c|c|c|c|c|c|c|c|c|}
\hline \multirow[t]{2}{*}{ Year } & \multicolumn{2}{|c|}{$\begin{array}{l}\text { Mean seed } \\
\text { yield }(q / h a)\end{array}$} & \multirow[t]{2}{*}{$\begin{array}{c}\% \\
\text { increase } \\
\text { in yield }\end{array}$} & \multicolumn{2}{|c|}{$\begin{array}{c}\text { Cost of } \\
\text { cultivation } \\
(\text { Rs/ha })\end{array}$} & \multicolumn{2}{|c|}{$\begin{array}{l}\text { Gross returns } \\
\quad(\text { Rs/ha })\end{array}$} & \multirow{2}{*}{$\begin{array}{l}\text { Additional } \\
\text { Net } \\
\text { returns } \\
(\text { Rs/ha })\end{array}$} & \multicolumn{2}{|c|}{$B: C$ ratio } \\
\hline & $I T$ & $L C$ & & $I T$ & $L C$ & $I T$ & $L C$ & & $I T$ & $L C$ \\
\hline $2015-16$ & 25.7 & 19.45 & 32.1 & 29240 & 30250 & 79670 & 50570 & 28090 & 2.72 & 1.67 \\
\hline 2016-17 & 27.85 & 24.12 & 15.4 & 29350 & 29193 & 115915 & 91640 & 24118 & 4.01 & 3.14 \\
\hline 2017-18 & 26.38 & 22.31 & 18.5 & 29584 & 29303 & 92333 & 73626 & 18426 & 3.19 & 2.51 \\
\hline Average & 27 & 22 & 22 & 29391 & 29582 & 95973 & 71945 & 23545 & 3 & 2 \\
\hline
\end{tabular}

Table.3 Productivity of castor, yield gaps and technology index

\begin{tabular}{|c|c|c|c|c|c|c|c|c|}
\hline \multirow[t]{2}{*}{ Year } & \multirow{2}{*}{$\begin{array}{c}\text { No. of } \\
\text { Demonstrations }\end{array}$} & \multicolumn{3}{|c|}{ Productivity (q/ha) } & \multirow{2}{*}{$\begin{array}{l}\text { \%increase } \\
\text { over local }\end{array}$} & \multirow{2}{*}{$\begin{array}{l}\text { Technology } \\
\text { gap }(q / h a)\end{array}$} & \multirow{2}{*}{$\begin{array}{c}\text { Extension } \\
\text { gap } \\
(q / h a)\end{array}$} & \multirow{2}{*}{$\begin{array}{c}\text { Technology } \\
\text { index }(\%)\end{array}$} \\
\hline & & Potential & $I T$ & $L C$ & & & & \\
\hline $2015-16$ & 10 & 30 & 25.70 & 19.45 & 32.1 & 4.3 & 6.3 & 14.3 \\
\hline 2016-17 & 10 & 30 & 27.85 & 24.12 & 15.5 & 2.2 & 3.7 & 7.2 \\
\hline $2017-18$ & 10 & 30 & 26.38 & 22.31 & 18.2 & 3.6 & 4.1 & 12.1 \\
\hline Average & 30 & 30.00 & 26.64 & 21.96 & 21.95 & 3.36 & 4.68 & 11.19 \\
\hline
\end{tabular}


More and more use of latest production technologies with high yielding varieties will subsequently change this alarming trend of galloping extension gap. Padmaiah et al., (2012) has also opined that depending on identification and use of farming situation, specific interventions may have greater implications in enhancing system productivity.

\section{Technology index}

The technology index shows the feasibility of the demonstrated technology at the farmer's field. The technology index varied from 7.2 to 14.3 per cent (Table 3 ). The technology index was minimum (7.2\%) in the year 2016-17 as compared to year 2017-18 (12.1\%) and 2015$16(14.3 \%)$. On an average technology index was observed 11.19 per cent during the three years of FLD programme, which shows the efficacy of good performance of technical interventions. This will accelerate the adoption of demonstrated technical intervention to increase the yield performance of castor. In Conclusion, it may be concluded that the yield and returns in castor crop increased substantially with the latest technology (Intervention) under real farming situation, which they have been advocating for long time. However, the yield level under FLDs was better than the farmer practice and performance of this variety could be further improved by adopting recommended production technologies. So, there is need to disseminate the improved technologies among the farmers with effective extension methods like training and field demonstrations. The farmers should be encouraged to adopt the recommended agro techniques for getting maximum returns in specific locations. With this study concluded that the FLDs programmes were effective in changing attitude, skill and knowledge of improved package and practices of HYV of castor adoption

\section{References}

Anonymous, (2013). Area, Production and Productivity (Districts). http://eands. dacnet.nic.in/.

Kumar Naik, A.H., Rudramuni, T., Hanumantha Naik, G. and Chandrappa, D. (2015). Yield gap analysis through front line demonstration in castor crop in Chitradurga districts of Karnataka. International Journal of Tropical Agriculture. 33(3): 2367-2371.

Padmaiah, M., Venkatkumar, R., Iswar singh, S., Solanki and Sarad, C. (2012). Castor (Ricinus communis L.) frontline demonstrations in Jodhpur district of Rajasthan: An impact study. Journal of Oilseeds Research. 29 (1): 84-88.

Romade, B. D., Deolankar K. P. and Gosavi, A. B. (2018). Yield and gap analysis of wheat productivity through frontline demonstrations organized by agricultural research station, NIPHAD. Guj. J. Ext. Edu. Special Issue on National Seminar: April 2018

Samui, S.K., Mitra S., Roy D.K., Mandal A. K. and Saha, D. (2000). Evaluation of front line demonstration on groundnut. Journal of the Indian Society Costal Agricultural Research 18(2): 180-183.

\section{How to cite this article:}

Prajapati, P.J., N.S. Joshi, M.L. Patel and Parmar, V.S. 2018. Yield Gap Analysis through Front Line Demonstration in Castor. Int.J.Curr.Microbiol.App.Sci. 7(11): 1677-1681. doi: https://doi.org/10.20546/ijcmas.2018.711.191 